\title{
Impact of Rural-Household Differentiation on the Action of Farmland Transfer
}

\author{
Lishuang Wang \\ College of Economics and Management \\ Shenyang Agricultural University \\ Shenyang, China \\ wangls2009@126.com \\ Chunping Wang \\ College of Economics and Management \\ Shenyang Agricultural University \\ Shenyang, China \\ wchp2002@163.com
}

\author{
Zhanxiang Sun \\ Tillage and Cultivation Research Institute \\ Liaoning Academy of Agricultural Science \\ Shenyang, China \\ libai200008@126.com \\ Wei Ma \\ College of Economics and Management \\ Shenyang Agricultural University \\ Shenyang, China \\ 27125807@qq.com
}

\begin{abstract}
Objective: The research analyzed empirically the impact of rural-household differentiation on the action of farmland transfer by Logistic model; Methods: Logistic Model; Results: It turned out that rural household vocational differentiation degree and rural household income differentiation degree existed significant positive impact on rural household behavior of outward transfer farmland, rural household vocational differentiation degree existed significant negative impact on rural household behavior of inward transfer farmland, rural household income differentiation degree existed significant positive impact on rural household behavior of inward transfer farmland. In addition, in the other control variables, householder culture degree, non-agricultural employment skills existed significant impact on rural household behavior of outward transfer farmland, householder age existed significant impact on rural household behavior of inward transfer farmland; Conclusion: Develop non-agricultural industries vigorously, strengthen the training of farmers employment skills, promote employment ability, change the structure of household income, expand income channel, increase the driving force of land transfer, realize the separation of rural household and farmland; Provide timely accurate agricultural market information, enhance the effect of agricultural science and technology on agricultural production, realize agriculture moderate scale management.
\end{abstract}

Keywords-Rural-Household Differentiation; Outward Transfer Farmland; Inward Transfer Farmland; Influence Factor; Logistic Model

\section{INTRODUCTION}

In the early 1980s, China introduced the household contract responsibility system in rural areas, realized the separation of farmland ownership and management rights. In a certain period, it increased the farmers' income, but this small-scale decentralized management mode brought farmland fragmentation. Farmland Transfer is one of the effective ways to resolve current our country rural area farmland fragmentation. Some scholars had done the related empirical studies on impact of rural household farmland transfer. These factors contained rural household's own characteristics and resource endowments[1], high transaction costs[2], incomplete farmland property rights[3] and absent rural social security mechanism[4].

Along with the advancement of rural marketization reform, the institutional obstacles of rural household participating in production were gradually resolved, especially the labor resources' flow enhanced significantly between urban-rural region. The difference of technical level and market participation ability between rural household led to a big difference on rural household's labor force employment structure and income structure, and rural-household differentiation occurred gradually through the cycle of difference self accumulation[5]. In the period of rural social differentiation increasingly prominent, it had a strong practical significance to study rural farmland transfer behavior from the perspective of rural-household differentiation. Using 385 rural household questionnaire survey data of Tieling, the research analyzed empirically the impact of rural-household differentiation on the action of farmland transfer, in the hope of offering reference for policy making to realize agriculture moderate scale management.

\section{DATA SOURCES AND RESEARCH METHOdS}

\section{A. Samples and Data}

The data was from rural household questionnaire survey of Changtu county and Tieling county Tieling city during November to December, 2013. Tieling city is located in the north of Lliaoning province, which is rich in agricultural resources and known as the granary of northern liaoning province, has four national commodity grain base counties, is the national major grain-producing area and national key commodity grain production base. In 2012, the farmland area was 8.2 million mu, grain output reached 3.867 million ton, and rural resident average net income reached 10569 yuan. The investigation adopted method of questionnaire and interviews, selected four towns, five villages in every town, 12 questionnaires in 
every village, sent 240 questionnaires, took back 220 effective questionnaires, questionnaire efficient reached $91.67 \%$. The questionnaire content mainly included householder characteristic, family characteristic, ruralhousehold differentiation characteristic and ruralhousehold behavior of farmland transfer.

In 220 samples, outward transfer farmland was 118 which accounted for $53.64 \%$, inward transfer farmland was 46 which accounted for $20.91 \%$. Householder average age was 47 in which $46 \sim 60$ years old accounted for $49.09 \%$; cultural degree of elementary school and junior high school were the vast majority $(56.37 \%)$; there were 147 agricultural labors and migrant workers which accounted for $66.82 \%$; family labor quantity of $2 \sim 3$ was 162 which

TABle 1 RuRAl Household SAMPLE Basic Situation

\begin{tabular}{|c|c|c|c|}
\hline Variable & Option & Sample & Proportion(\%) \\
\hline \multirow{3}{*}{$\begin{array}{l}\text { Farmland } \\
\text { transfer } \\
\text { behavior }\end{array}$} & $\begin{array}{l}\text { Outward transfer } \\
\text { farmland }\end{array}$ & 118 & 53.64 \\
\hline & Inward transfer & 46 & 20.91 \\
\hline & $\begin{array}{l}\text { Without transfer } \\
\text { farmland }\end{array}$ & 56 & 25.45 \\
\hline \multirow{4}{*}{$\begin{array}{l}\text { Householder } \\
\text { age }\end{array}$} & Less than 30 years old & 23 & 10.45 \\
\hline & $30 \sim 45$ years old & 73 & 33.18 \\
\hline & $46 \sim 60$ years old & 108 & 49.09 \\
\hline & More than 60 years old & 16 & 7.27 \\
\hline \multirow{4}{*}{$\begin{array}{l}\text { Householder } \\
\text { culture degree }\end{array}$} & $\begin{array}{l}\text { Less than primary } \\
\text { school }\end{array}$ & 43 & 19.55 \\
\hline & Primary school & 59 & 26.82 \\
\hline & Junior high school & 65 & 29.55 \\
\hline & $\begin{array}{l}\text { More than junior high } \\
\text { school }\end{array}$ & 53 & 24.09 \\
\hline \multirow{2}{*}{$\begin{array}{l}\text { Householder } \\
\text { health status }\end{array}$} & Yes & 208 & 94.55 \\
\hline & No & 12 & 5.45 \\
\hline \multirow{3}{*}{$\begin{array}{l}\text { Householder } \\
\text { professional } \\
\text { types }\end{array}$} & $\begin{array}{l}\text { Agricultural labor, } \\
\text { migrant worker }\end{array}$ & 147 & 66.82 \\
\hline & $\begin{array}{l}\text { Farmer intellectual, } \\
\text { individual business }\end{array}$ & 43 & 19.55 \\
\hline & $\begin{array}{l}\text { Private enterprise, rural } \\
\text { administrators }\end{array}$ & 30 & 13.64 \\
\hline \multirow{3}{*}{$\begin{array}{c}\text { Family labor } \\
\text { quantity }\end{array}$} & $0 \sim 1$ people & 9 & 4.09 \\
\hline & $2 \sim 3$ people & 162 & 73.64 \\
\hline & More than 3 people & 49 & 22.27 \\
\hline \multirow{3}{*}{$\begin{array}{l}\text { Annual } \\
\text { household } \\
\text { income }\end{array}$} & Less than 10000 yuan & 7 & 3.18 \\
\hline & $10000 \sim 30000$ yuan & 118 & 53.64 \\
\hline & More than 30000 yuan & 95 & 43.18 \\
\hline \multirow{3}{*}{$\begin{array}{l}\text { Family } \\
\text { cultivated } \\
\text { land area }\end{array}$} & Less than $10 \mathrm{~km}$ & 29 & 13.18 \\
\hline & $10 \sim 50 \mathrm{~km}$ & 150 & 68.18 \\
\hline & More than $50 \mathrm{~km}$ & 21 & 9.55 \\
\hline \multirow{2}{*}{$\begin{array}{c}\text { Non- } \\
\text { agricultural } \\
\text { employment } \\
\text { skills }\end{array}$} & Yes & 86 & 39.09 \\
\hline & No & 134 & 60.91 \\
\hline
\end{tabular}

accounted for 73.64\%; annual household income of $10000 \sim 30000$ yuan was 118 which accounted for 53.64\%; family cultivated land area of $10 \sim 50 \mathrm{mu}$ was 150 which accounted for $68.18 \%$; having non-agricultural employment skills was 86 which accounted for $39.09 \%$. The basic situation of rural household sample were shown in table 1.

\section{B. Model Selection}

This research adopted Logistic regression model for quantitative analysis impact of rural-household differentiation on the action of farmland transfer. Householder characteristic, family characteristic, ruralhousehold differentiation characteristic were independent variables, and rural-household behavior of farmland transfer (y) was dependent variable. The function in (1):

$\mathrm{y}=\mathrm{f}$ (householder characteristic, family characteristic, rural-household differentiation characteristic) + random perturbed variable

The basic form of model was as follows:

$$
P(y=1)=\frac{\operatorname{Exp}\left(\beta_{0}+\beta_{1} x_{1}+\mathrm{L}+\beta_{j} x_{j}\right)}{1+\operatorname{Exp}\left(\beta_{0}+\beta_{1} x_{1}+\mathrm{L}+\beta_{j} x_{j}\right)}
$$

In (2), If rural household had the behavior of inward (outward) transfer farmland, the dependent variable was 1 , if not, the dependent variable was $0 ; \beta_{0}$ was constant term; $x_{j}$ were impact factors of rural household farmland transfer; $\beta_{j}$ was partial regression coefficient of ${ }^{x_{j}}$.

\section{Variable Selection}

The independent variables were divided into the following several aspects[6-9].

- Householder and family characteristic variables were householder age, householder cultural degree, householder health, farmland area, nonagricultural employment skills.

- Rural-household differentiation characteristic variables were rural household differentiation type, rural household vocational differentiation degree and rural household income differentiation degree. Referring to the research of Xueyi Lu[10], rural household differentiation type included agricultural labor, migrant worker, farmer intellectual, individual business, private enterprise, rural administrator. Rural household vocational differentiation degree was the proportion of nonagricultural labor force accounts for the total labor force. Rural household income differentiation degree was the proportion of non-agricultural income accounts for the total income. Variables were defined in table 2. 
TABLE 2. FARMLAND TRANSFER BEHAVIOR INFLUENCE FACTOR VARIABLES

\begin{tabular}{|c|c|c|c|}
\hline Category & Variables & Mark & Variable Definition \\
\hline $\begin{array}{l}\text { Farmland } \\
\text { transfer } \\
\text { behavior }\end{array}$ & $\begin{array}{c}\text { Outward } \\
\text { transfer } \\
\text { farmland } \\
\text { Inward transfer } \\
\text { farmland } \\
\end{array}$ & $\mathrm{y}$ & $\begin{array}{l}\text { Yes }=1 ; \mathrm{No}=0 \\
\text { Yes }=1 ; \mathrm{No}=0\end{array}$ \\
\hline & Householder age & $\mathrm{x}_{1}$ & Numeric variables \\
\hline $\begin{array}{l}\text { Householder } \\
\text { characteristic }\end{array}$ & $\begin{array}{l}\text { Householder } \\
\text { cultural degree } \\
\text { Householder } \\
\text { health }\end{array}$ & $\mathrm{x}_{3}$ & $\begin{array}{l}\text { Numeric variables } \\
\qquad \mathrm{Yes}=1 ; \mathrm{No}=0\end{array}$ \\
\hline $\begin{array}{c}\text { Family } \\
\text { characteristic }\end{array}$ & $\begin{array}{c}\text { Farmland area } \\
\text { Non-agricultural } \\
\text { employment } \\
\text { skills }\end{array}$ & $\mathrm{x}_{4}$ & Numeric variables \\
\hline $\begin{array}{c}\text { Rural- } \\
\text { household } \\
\text { differentiation }\end{array}$ & $\begin{array}{l}\text { Rural household } \\
\text { vocational } \\
\text { differentiation } \\
\text { degree } \\
\text { Rural household } \\
\text { income } \\
\text { differentiation } \\
\text { degree }\end{array}$ & $\mathrm{x}_{8}$ & $\begin{array}{c}\text { Agricultural labor }=1 \text {, } \\
\text { migrant worker }=2, \\
\text { farmer intellectual=3, } \\
\text { individual business }=4 \text {, } \\
\text { private enterprise }=5 \text {, } \\
\text { rural administrator }=6 \\
\text { Proportion of non- } \\
\text { agricultural labor force } \\
\text { accounts for the total } \\
\text { labor force } \\
\text { Proportion of non- } \\
\text { agricultural income } \\
\text { accounts for the total } \\
\text { income }\end{array}$ \\
\hline
\end{tabular}

\section{MODEL RUN}

The article used Logistic model to analyze the related data of rural household farmland transfer behavior by SPSS 16.0 statistical software. The independent variables were put into the regression model, and it got the not standardized coefficient. The results were shown in table 3 , and the model test results were significant.

\section{RESUltS ANALYSIS}

\section{A. Behavior Analysis of Outward Transfer Farmland}

\section{1) Rural-household differentiation variables}

The results showed that, rural-household differentiation type had no significant influence on behavior of outward transfer farmland. Rural household vocational differentiation degree had significant positive influence on behavior of outward transfer farmland. It showed that the higher rural household vocational differentiation degree, the higher the proportion of nonagricultural labor force accounts for the total labor force, the more possibility of outward transfer farmland. The reason was that rural household who had less labor force engaging in agricultural production were more likely to outward transfer farmland. Rural household income differentiation degree had significant positive influence on behavior of outward transfer farmland. It showed that the higher rural household income differentiation degree, the higher the proportion of non-agricultural income accounts for the total income, the more possibility of outward transfer farmland. The reason was that the family labor force of higher non-agricultural income proportion was insufficient in Agricultural production.

TABle 3. Model Estimate Result of RuRal Household OUTWARd (INWARD) TRANSFER FARMLAND BEHAVIOR

\begin{tabular}{|c|c|c|c|c|c|c|}
\hline \multirow{2}{*}{ Variables } & \multicolumn{3}{|c|}{$\begin{array}{c}\text { Outward Transfer } \\
\text { Farmland }\end{array}$} & \multicolumn{3}{|c|}{$\begin{array}{c}\text { Inward Transfer } \\
\text { Farmland }\end{array}$} \\
\hline & $\beta$ & Sig. & $\operatorname{Exp}(\beta)$ & $\beta$ & Sig. & $\operatorname{Exp}(\beta)$ \\
\hline $\begin{array}{l}\text { Householder } \\
\text { Age }\end{array}$ & 0.041 & 0.327 & 1.042 & $0.329 * *$ & 0.038 & 1.390 \\
\hline $\begin{array}{l}\text { Householder } \\
\text { Cultural } \\
\text { Degree }\end{array}$ & $0.126^{* *}$ & 0.021 & 1.135 & 0.393 & 0.174 & 1.482 \\
\hline $\begin{array}{l}\text { Householder } \\
\text { Health }\end{array}$ & -0.092 & 0.168 & 0.912 & 0.372 & 0.166 & 1.451 \\
\hline $\begin{array}{l}\text { Farmland } \\
\text { Area }\end{array}$ & 0.298 & 0.227 & 1.348 & -0.051 & 0.241 & 0.950 \\
\hline $\begin{array}{l}\text { Non- } \\
\text { agricultural } \\
\text { Employment } \\
\text { Skills }\end{array}$ & $0.279 * *$ & 0.036 & 1.322 & -0.640 & 0.246 & 0.527 \\
\hline $\begin{array}{l}\text { Rural } \\
\text { Household } \\
\text { Differentiation } \\
\text { Type }\end{array}$ & -2.189 & 0.618 & 0.112 & -2.407 & 0.100 & 0.090 \\
\hline $\begin{array}{l}\text { Vocational } \\
\text { Differentiation } \\
\text { Degree }\end{array}$ & $0.289 * *$ & 0.039 & 1.336 & $-0.116^{*}$ & 0.094 & 0.890 \\
\hline $\begin{array}{l}\text { Income } \\
\text { Differentiation } \\
\text { Degree }\end{array}$ & $0.927 * *$ & 0.028 & 2.528 & $0.165^{* *}$ & 0.016 & 1.180 \\
\hline $\begin{array}{l}\text { Constant } \\
\text { Term }\end{array}$ & -3.352 & 0.003 & 0.035 & -0.923 & 0.524 & 0.397 \\
\hline $\begin{array}{l}-2 \log \\
\text { likelihood }\end{array}$ & & 91.385 & & & 88.726 & \\
\hline Nagelkerke $\mathrm{R}^{2}$ & & 0.348 & & & 0.383 & \\
\hline Sig. & & 0.000 & & & 0.000 & \\
\hline
\end{tabular}

Notes: ${ }^{*}{ }^{* *}$ are respectively significant under $10 \%, 5 \%$ levels.

\section{2) The other control variables}

Householder culture degree, non-agricultural employment skills existed significant impact on rural household behavior of outward transfer farmland. The higher householder culture degree, the more possibility of outward transfer farmland. The reason was that the householder with high culture degree was more likely to enter into the non-agricultural employment field. The higher non-agricultural employment skills, the more possibility of outward transfer farmland. The reason was that the rural household with higher non-agricultural employment skills was more likely to ether into the nonagricultural fields and obtain higher income.

\section{B. Behavior Analysis of Inward Transfer Farmland}

\section{1) Rural-household differentiation variables}

The results showed that, rural-household differentiation type had no significant influence on 
behavior of inward transfer farmland. Rural household vocational differentiation degree had significant negative influence on behavior of inward transfer farmland. It showed that the higher rural household vocational differentiation degree, the higher the proportion of nonagricultural labor force accounts for the total labor force, the less possibility of inward transfer farmland. The reason was that rural household who had less labor force engaging in non-agricultural production (more labor force engaging in agricultural production) were more likely to inward transfer farmland. Rural household income differentiation degree had significant positive influence on behavior of inward transfer farmland. It showed that the higher rural household income differentiation degree, the higher the proportion of non-agricultural income accounts for the total income, the more possibility of inward transfer farmland. The reason was that rural household who had more income were more likely to inward transfer farmland to achieve scale management.

\section{2) The other control variables}

Householder age existed significant positive impact on rural household behavior of inward transfer farmland. The higher householder age, the more possibility of inward transfer farmland. The reason was that the householder with high age was more likely to expand the scale of agricultural production to increase income by inward transfer farmland.

\section{CONCLUSIONS AND POLICY IMPLICATIONS}

The research analyzed empirically the impact of rural-household differentiation on the action of farmland transfer by Logistic model. It turned out that rural household vocational differentiation degree and rural household income differentiation degree existed significant positive impact on rural household behavior of outward transfer farmland, rural household vocational differentiation degree existed significant negative impact on rural household behavior of inward transfer farmland, rural household income differentiation degree existed significant positive impact on rural household behavior of inward transfer farmland. In addition, in the other control variables, householder culture degree, non-agricultural employment skills existed significant impact on rural household behavior of outward transfer farmland, householder age existed significant impact on rural household behavior of inward transfer farmland.

Based on the above conclusions the article gives the suggestion. Develop non-agricultural industries vigorously, strengthen the training of farmers employment skills, promote employment ability, change the structure of household income, expand income channel, increase the driving force of land transfer, realize the separation of rural household and farmland; Provide timely accurate agricultural market information, enhance the effect of agricultural science and technology on agricultural production, realize agriculture moderate scale management.

\section{ACKNOWLEDGMENT}

This research was supported by the Special Fund for Agro-scientific Research in the Public Interest (201103001,201303130); Agricultural Key Research Projects in Liaoning Province ( 2014213004 ) ; Key Projects in the National Science \& Technology Pillar Program during the 12th Five-year Plan Period (2012BAD09B00); Natural Foundation of Liaoning Province (2014027025); Non-profit Institute Fund(BSRF201403).

\section{REFERENCES}

[1] Kechun Liu and Weihua Su. "Rural-household resource endowment, transaction cost and farmland transfer behaviour-based on rural-household survey in Jiangxi province". Statistical study, May 2006, pp.73-77.

[2] Tao Li, Yiguang Ye and Wenhua Sun. "Transaction cost analysis of rural collective land ownership circulation". China's rural economy, Dec. 2004, pp.10-15.

[3] Taiyang Zhong, Xinjin Huang and Ping Kong. "Research of farmland property rights and rural-household land leasing intention." China's land science, vol. 19, Jan. 2005, pp.49-55.

[4] Xiaohuan Yan and Xuexi Huo. "Peasant employment, rural social security and farmland transfer--based on the analysis of 479 farmers in Henan province". Agricultural technology economy,Jul. 2013, pp.34-44.

[5] Xianbao Li and Qiang Gao. "Behavior logic, differentiation result and development prospects--based on the investigation of ruralhousehold differentiation behavior in China since 1978". Agricultural economic problems, Feb. 2013, pp.56-65.

[6] Zhaorong Dong and Changyun.Jiang "Impact of rural-household internal factors on rural-household type selection and differentiation". Journal of anhui agricultural university (social science edition), Jan. 1996, pp.37-40.

[7] Wenhua Sun. "Rural-household differentiation: microscopic mechanism and empirical analysis". Jianghai journal, Apr. 2008, pp.114-119.

[8] Ge Wei. "Causes and evaluation on formation of concurrentbusiness farmers in China". Journal of huazhong university of science and technology (social science edition), Mar. 1998, pp.6568.

[9] Heng-zhou Xu and Shuqin Shi. "Impact of Farmer Differentiation on Farm Households Willingness in Farmland Transference" China population resources and environment, vol. 22, Feb. 2012, pp.9096.

[10] Xueyi Lu and Houyi Zhang. "Peasant differentiation, problems and countermeasures". Agricultural economic problems, Jan. 1990, pp.16-21. 